\title{
ФОРМУВАННЯ ІНШОМОВНОЇ КОМУНІКАТИВНОЇ КОМПЕТЕНТНОСТІ ВІЙСЬКОВОСЛУЖБОВЦІВ У ПРОЦЕСІ ДИСТАНЦЙНОГО НАВЧАННЯ
}

\author{
Жукевич I. П. \\ кандидат педагогічних наук, дочент, \\ доиент спеиіальної кафедри № 2 \\ Інститут Управління державної охорони Украӥни \\ Київського національного університету імені Тараса Шевченка \\ вул. П. Болбочана, 8, Київ, Украӥна \\ orcid.org/0000-0002-4109-4336 \\ i.zhukevych@ukr.net \\ Спірічева О. В. \\ старший викладач спеціальної кафедри № 2 \\ Інститут Управління державної охорони Украӥни \\ Київського начіонального університету імені Тараса Шевченка \\ вул. П. Болбочана, 8, Київ, Україна \\ orcid.org/0000-0001-5686-0024 \\ spire3108@ukr.net
}

\section{Ключові слова:}

іншомовна комунікативна компетентність, структурні компоненти комунікативної компетентності, дистаниійний формат навчання, рівень володіння іноземною мовою, форми дистаниійного формату навчання, компетентнісний niдxid.
Статтю присвячено питанню формування іншомовної комунікативної компетентності військовослужбовців Інституту Управління державної охорони України в умовах дистанційного навчання. Проаналізовано основні підходи до визначення сутності поняття іншомовної комунікативної компетентності, визначено основні структурні компоненти та особливості іiі формування для військовослужбовців Інституту УДО України. Іншомовну комунікативну компетентність військовослужбовців Інституту УДО України слід розглядати як набуту у навчальному процесі здатність особистості до реалізації комунікативних моделей іншомовної поведінки у стереотипних комунікативних ситуаціях професійного спрямування. Навчання іноземної мови передбачає узагальнення та вдосконалення базового рівня володіння іноземною мовою у зв'язку з поглибленою профільною мовною підготовкою, спрямованою на використання отриманих знань у сфері подальшої професійної діяльності. Враховуючи реалії сучасного життя, проаналізовано особливості застосування дистанційного формату навчання, з'ясовано основні його форми та способи реалізації. Формування іншомовної комунікативної компетентності можливе в результаті організації таких заходів, як: використання месенджерів та соціальних мереж для організації зворотного зв'язку зі студентами/ слухачами (Google Meet, Microsoft Teams, Moodle тощо); систематична організація роботи 3 аутентичними відео- та аудіоресурсами професійного та загального спрямування; використання інтерактивних технологій, що здатні активізувати комунікативні уміння у дистанційному форматі (рольові ігри, метод проєктів, кейс-методи, презентації тощо); застосування цифрових засобів візуалізації (Quizlet, Duolingo, Mindmap, Classtoolsnet). Визначено поняття дистанційних технологій навчання іноземної мови та охарактеризовано оптимальні умови їх використання. Перспективним виявляється раціональне та методично обгрунтоване поєднання дистанційних форм навчання, які 
дадуть змогу створити та реалізувати компетентісно орієнтовані завдання, що сприятимуть оволодінню студентами знаннями, уміннями, навичками та набуттю особистісних якостей, поведінкових та комунікативних стратегій, характерних для формування іншомовної комунікативної компетентності військовослужбовців Інституту УДО України. Визначено перспективи подальших досліджень, які вимагають проведення аналізу нових форм дистанційного навчання та можливості їх застосування 3 урахуванням компетентісного підходу у навчанні іноземної мови.

\title{
FORMATION OF FOREIGN LANGUAGE COMMUNICATIVE COMPETENCE OF MILITARY SERVICEMEN IN THE PROCESS OF DISTANCE TEACHING
}

\author{
Zhukevych I. P. \\ Ph. D. in Pedagogy, Associate Professor, \\ Associate Professor at the Special Department № 2 \\ Institute of the Department of State Guard of Ukraine \\ of Taras Shevchenko National University of Kyiv \\ Bolbochana str., 8, Kyiv, Ukraine \\ orcid.org/0000-0002-4109-4336 \\ i.zhukevych@ukr.net \\ Spiricheva O. V. \\ Senior Lecturer at the Special Department № 2 \\ Institute of the Department of State Guard of Ukraine \\ of Taras Shevchenko National University of Kyiv \\ Bolbochana str., 8, Kyiv, Ukraine \\ orcid.org/0000-0001-5686-0024 \\ spire3108@ukr.net
}

Key words: foreign language communicative competence, structural components of communicative competence, distance teaching format, level of foreign language proficiency, forms of distance teaching format, competence approach.
The article is devoted to the issue of formation of foreign language communicative competence of servicemen of the Institute of the Department of State Guard of Ukraine (further - Institute of the DSGU) in the conditions of distance teaching. The main approaches to defining the essence of the concept of foreign language communicative competence are analyzed, the main structural components and features of its formation for servicemen of the Institute of the DSGU are determined. The foreign language communicative competence of the servicemen of the Institute of the DSGU should be considered as the ability of the individual to realize communicative models of foreign language behavior in stereotypical communicative situations of professional purposes acquired in the educational process. Foreign language teaching involves the generalization and improvement of the basic level of foreign language proficiency in connection with in-depth specialized language training aimed at the application of the acquired knowledge in the field of further professional activity. Taking into account the realities of modern life, the peculiarities of the application of distance teaching format are analyzed, its main forms and methods of implementation are clarified. The formation of foreign language communicative competence is possible as a result of the organization of the following activities: the use of messengers and social networks to organize feedback with students (Google Meet, Microsoft Teams, Moodle, etc.); systematic organization of work with authentic video and audio resources of professional and general purposes; application of interactive technologies enable to activate communication skills in a remote format (role-playing games, project method, case methods, presentations, etc.); 
application of digital visualization tools (Quizlet, Duolingo, Mindmap, Classtoolsnet). The concept of distance teaching technologies of a foreign language is defined and the optimal conditions of their usage are characterized. A perspective rational and methodological combination of distance teaching will create and implement competencyoriented tasks that can help students master the knowledge, skills, abilities and acquisition of personal qualities, behavioral and communicative strategies for the foreign language communicative competence of servicemen of the Institute of the DSGU. Prospects for further research that require analysis of new forms of distance teaching and the possibility of their application are to be considered within the competence approach in foreign language teaching.

Постановка проблеми. Розвиток міжнародних відносин, інтеграція України в європейське та світове суспільство зумовлюють здійснення державної охорони під час візитів осіб, що охороняються, до іноземних країн, а також забезпечення безпеки міжнародних представників на території України. Формування іншомовної комунікативної компетентності військовослужбовців Інституту Управління державної охорони України (далі - Інститут УДО України) $є$ необхідною умовою виконання їхніх професійних обов'язків, забезпечуючи ефективну комунікацію, професійну співпрацю між партнерами та обмін досвідом. Комп'ютеризація сьогоднішнього життя, зміна способів сприйняття інформації, події, пов'язані з розповсюдженням вірусу COVID-19, зумовлюють застосування цифрових платформ навчання, інноваційні формати викладання на основі інформаційних та мобільних технологій. Необхідність здійснювати навчальний процес дистанційно передбачає пошук нових підходів, форм, методів, технологій навчання іноземної мови.

Аналіз останніх досліджень та публікацій. Проблемі дослідження іншомовної комунікативної компетентності присвячено багато наукових досліджень, проте, 3 огляду на сучасні вимоги суспільства, вона залишається актуальною. Визначенню поняття іншомовної комунікативної компетентності присвятили свої дослідження зарубіжні та вітчизняні вчені: Н. Хомський, І.О. Зимня, С.Ю. Ніколаєва, О.В. Падей, В.М. Ростовцева та інші. Питання дистанційних форм навчання досліджували О.О. Захарова, М.Д. Горячев, М.М. Горячев, Є.С. Полат, К.Ю. Кожухов, Н.В. Іванушкіна, Н.В. Майєр, М.В. Мантуленко та інші. Незважаючи на наявність значного доробку у цій сфері, актуальним стає питання формування іншомовної комунікативної компетентності саме в умовах дистанційного формату навчання. Це i зумовлює актуальність нашого дослідження.

Мета статті - аналіз сучасного стану формування іншомовної комунікативної компетентності в умовах дистанційного навчання.

Виклад основного матеріалу дослідження. На думку дослідника О.В. Нефедова, іншомовна комунікативна компетентність - це здатність та готовність до іншомовного спілкування з носіями мови, сприйняття та розуміння партнерів, адек- ватного та вчасного вираження своїх розумових намірів [1, с. 143]. Дослідниця В.М. Ростовцева визначає іншомовну комунікативну компетентність як сукупність знань, умінь, навичок та якостей (особистісних та професійно значущих), а також здатність до присвоєння нових знань $\mathrm{i}$ досвіду та готовність до їх реалізації на практиці [2, с. 635]. I.О. Зимня характеризує компетентність як обгрунтовану знаннями, інтелектуально та особистісно зумовлену соціально-професійну життєдіяльність людини. На іï думку, поняття «компетентність» трактується як здатність людини до практичної діяльності, а компетенція - змістовний компонент цієї здатності у вигляді знань, умінь та навичок [3, с. 55-56].

Зважаючи на зміни у суспільстві, соціальній реальності життя, змінюються цілі навчання іноземної мови. Відповідно, іншомовна комунікативна компетентність - це готовність особистості до адаптації у професійній сфері, набута в умовах дистанційного формату навчання.

Згідно із Загальноєвропейськими рекомендаціями 3 мовної освіти, комунікативна компетентність інтегрує лінгвістичну, соціолінгвістичну та прагматичну компетенції. Лінгвістична компетенція включає фонологічні, лексичні, граматичні знання та вміння. Соціолінгвістична визначається соціокультурними умовами використання мови, являючи собою сполучну ланку між комунікативною та іншими компетенціями. Прагматична компетенція містить екстралінгвістичні елементи спілкування (міміку, жестикуляцію тощо) [4, с. 46]. На думку Є.А. Рубцової, формування іншомовної комунікативної компетентності базується на сукупності мовної, мовленнєвої, соціокультурної та лінгвістичної компетенцій. Мовна компетенція передбачає знання системи мови, граматичних правил іï використання. Мовленнєва компетенція - сукупність знань, умінь, навичок вільної, ефективної мовленнєвої поведінки у різноманітних комунікативних ситуаціях. Соціокультурна компетенція містить знання національних культурних особливостей соціальної та мовленнєвої поведінки носіїв мови. Лінгвістична компетенція включає знання відомостей про мову, вміння співвідносити мовні засоби з умовами спілкування, вміння організовувати мовленнєве спілкування 3 урахуванням соціальних норм поведінки [5, с. 66]. 
Отже, іншомовну комунікативну компетентність військовослужбовців Інституту УДО України слід розглядати як набуту у навчальному процесі здатність особистості до реалізації комунікативних моделей іншомовної поведінки у стереотипних комунікативних ситуаціях. Навчання іноземної мови передбачає узагальнення та вдосконалення базового рівня володіння іноземною мовою у зв'язку з поглибленою профільною мовною підготовкою, спрямованою на використання отриманих знань у сфері подальшої професійної діяльності.

Таким чином, набуття військовослужбовцями Інституту УДО України іншомовної комунікативної компетентності передбачає такий рівень володіння іноземною мовою, який дасть змогу використовувати його для задоволення професійних потреб, реалізації ділових та особистих контактів, успішного іншомовного ділового спілкування в межах професійної діяльності, а також із метою подальшої самоосвіти та обміну професійним досвідом.

Відповідно до Загальноєвропейських рекомендацій $з$ мовної освіти рівень володіння іноземною мовою для військовослужбовців Інституту УДО України має бути не нижче рівня В2. Враховуючи те, що початковий рівень володіння мовою вступників різний, обмежену кількість годин відповідно до навчального плану, пріоритет та домінування профільних дисциплін, особливого значення набуває раціоналізація процесу формування іншомовної комунікативної компетентності військовослужбовців Інституту УДО України. Пошук нових підходів, форм, методів, технологій навчання іноземної мови сприятиме усвідомленому вивченню іноземної мови. Наочність, доступність відео- та аудіоматеріалів, можливість самоконтролю та самоаналізу, зв'язок із профільними дисциплінами, використання стереотипних комунікативних ситуацій формує свідоме ставлення, зацікавленість та бажання до вдосконалення комунікативних навичок.

Безумовно, велике значення у формуванні іншомовної комунікативної компетентності належить живій комунікації, реалізація якої у дистанційному форматі можлива в результаті організації таких заходів, як: використання месенджерів та соціальних мереж для організації зворотного зв'язку зі студентами/слухачами (Google Meet, Microsoft Teams, Moodle тощо); систематична організація роботи з аутентичними відео- та аудіоресурсами професійного та загального спрямування; використання інтерактивних технологій, що здатні активізувати комунікативні уміння у дистанційному форматі (рольові ігри, метод проєктів, кейс-методи, презентації тощо); застосування цифрових засобів візуалізації (Quizlet, Duolingo, Mindmap, Classtoolsnet).
Визначаючи поняття дистанційних технологій навчання іноземної мови ми вважаємо, що технології навчання, що використовуються із застосуванням інформаційних та телекомунікаційних технологій під час віддаленої взаємодії викладача та студента. Серед сучасних форм навчання у дистанційному форматі слід зазначити: відеоконференції, аудіоконференції, комп'ютерні телеконференції, відеолекції, заняття у чаті, вебінари, радіозв'язок, телевізійні канали. 3 метою оптимізації навчального процесу види навчання іноземної мови у дистанційному форматі можна використовувати окремо або комплексно, що дасть змогу зробити процес навчання більш різноманітним, цікавішим та продуктивнішим.

Відеоконференції - це форма дистанційного навчання, що забезпечує двосторонній аудіо-, відеозв'язок між викладачем та студентами/слухачами. Важливою характеристикою цієї форми $\epsilon$ наявність візуального контакту в режимі реального часу. Викладач може представляти інформацію за допомогою функції демонстрації екрану, контролювати ступінь розуміння дисципліни, коригувати зацікавленість, ставити запитання та бачити реакцію студентів.

Аудіоконференції - форма електронної конференції, під час якої учасники використовують телефони або інші прилади для голосових повідомлень. Викладач може займатися з одним студентом або групою студентів.

Комп'ютерні телеконференції - це відеоконференції із застосуванням ПК, обладнаних мікрофонами та відеокамерами. Таку форму навчання оптимально використовувати з метою організації колективної роботи: рольові ігри, інтелектуальні конкурси тощо.

Відеолекції - це форма дистанційного навчання, в якій можуть транслюватися записи лектора $з$ динамічним зображенням: кінофрагменти, таблиці тощо. Цифрові файли зберігаються на електронному носії або веб-сервері. Студент може самостійно регулювати процес відеолекції, повертатися до попередніх розділів чи складних тем.

Заняття у чаті проводяться 3 використанням чатів (електронної системи спілкування) шляхом обміну текстовими повідомленнями, які можуть бачити всі учасники групи.

Вебінари - дистанційні семінари, конференції, форуми, що проводяться з використанням телекомунікаційних засобів та мережі Інтернет. Використовуються переважно для групового обговорення певної тематики. Під час обговорення та в будь-який зручний час учасники можуть робити дописи на сайті, коментувати матеріал, ставити питання.

Радіозв'язок - традиційна форма дистанційного навчання, перевагами якої є доступність для широкого кола аудиторії. 
Телебачення і радіозв'язок - уже не такі популярні форми дистанційного навчання, як відеоконференції та вебінари, оскільки не забезпечують зворотний зв'язок викладача та студентів онлайн. Доцільне застосування для перегляду прямого включення новин та live-peпортажів [6].

Таким чином, формування іншомовної комунікативної компетентності військовослужбовців Інституту УДО України потребує внесення якісних змін у навчальний процес за рахунок ефективної організації навчальної діяльності у дистанційному форматі. Для вирішення цієї проблеми перспективним виявляється раціональне та методично обгрунтоване поєднання дистанційних форм навчання, які дадуть змогу створити та реалізувати компетентісно орієнтовані завдання, що сприятимуть оволодінню слухачами знаннями, уміннями, навичками та набуттю особистісних якостей, поведінкових та комунікативних стратегій, характерних для формування іншомовної комунікативної компетентності військовослужбовців Інституту УДО України.

Висновки і перспективи подальших розробок у цьому напрямі. Аналіз відомих підходів до сутності поняття «іншомовна комунікативна

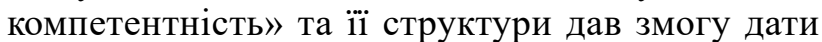
визначення цього поняття щодо військовослужбовців Інституту УДО України, що визначає їхню готовність та здатність ефективно здійснювати іншомовну комунікацію професійного спрямування шляхом іiі набуття та вдосконалення у форматі дистанційного навчання.

Подальшого дослідження вимагає аналіз форм дистанційного навчання та можливості їх застосування 3 урахуванням компетентнісного підходу у навчанні іноземної мови.

\section{ЛІТЕРАТУРА}

1. Нефедов О.В. Индикаторы рациональности рациональной методики обучения иноязычной коммуникативной компетенции студентов неязыковых вузов. Теория и практика общественного развития. 2015. № 4. C. 143-148. URL: https://cyberleninka.ru/article/n/indikatory-ratsionalnostiratsionalnoy-metodikiobucheniya-inoyazychnoy-kommunikativnoy-kompetentsii-studentovneyazykovyh-vuzo.

2. Ростовцева В.М. Парадигмальные научно-педагогические ориентиры совершенствования процесса подготовки преподавательских кадров для инновационного университета. Известия Самарского научного иентра Российской академии. 2013. Т. 15. № 2-3. C. 635-637. URL: https://cyberleninka.ru/ article/n/paradigmalnye-nauchno-pedagogicheskieorientiry-sovershenstvovaniya-protsessapodgotovkiprepodavatelskih-kadrov-dlya.

3. Зимняя И.А. Психология обучения иностранным языкам в школе. Москва: Просвещение, 1991. $222 \mathrm{c}$.

4. Common European framework of reference for languages: learning, teaching, assessment - Companion volume with new descriptors / Council of Europe. Strasburg: Council of Europe publishing. URL: www.coe.int/lang-cefr.

5. Рубцова Е.А. Формирование коммуникативной компетенции студентов в процессе обучения иностранному языку на базе LMS Moodle. Вестник Самарского университета. История, педагогика, филология. 2018. Т. 24. № 2. С. 63-69. URL: https://doi.org/10.18287/2542-0445-2018-24-2-63-69.

6. Современные формы удаленного обучения. 2020. URL: https:/edunews.ru/onlajn/info/vidydistantsionnogo-obucheniya.html.

\section{REFERENCES}

1. Nefedov O.V. (2015) Indikatory ratsionalnosti ratsionalnoi metodiki obucheniia inoyazychnoi kommunikativnoi kompetentsii studentov neyazykovykh vuzov [Indicators of the rationality of a rational methodology of teaching foreign language communicative competence of students of non-linguistic universities]. Theory and practice of social development. № 4. P. 143-148. URL: https:/cyberleninka.ru/ article/n/indikatory-ratsionalnosti-ratsionalnoy-metodikiobucheniya-inoyazychnoy-kommunikativnoykompetentsii-studentov-neyazykovyh-vuzo.

2. Rostovtseva V.M. (2013) Paradigmalnye nauchno-pedagogicheskie orientiry sovershenstvovaniya protsessa podgotovki prepodavatelskikh kadrov dlia innovatsionnogo universiteta [Paradigmatic scientific and pedagogical guidelines for improving the process of training teaching staff for an innovative university]. News of the Samara Scientific Center of the Russian Academy. V. 15. № 2-3. P. 635-637. URL: https://cyberleninka.ru/article/n/paradigmalnye-nauchno-pedagogicheskieorientiry-sovershenstvovaniyaprotsessa-podgotovkiprepodavatelskih-kadrov-dlya. 
3. Zymniaya I.A. (1991) Psykhologiya obucheniia inostrannym yazykam v shkole [Psychology of teaching foreign languages at school]. Moscow: Prosveshcheniye. $222 \mathrm{p}$.

4. Common European framework of reference for languages: learning, teaching, assessment - Companion volume with new descriptors / Council of Europe. Strasburg: Council of Europe publishing. URL: www.coe.int/lang-cefr.

5. Rubtsova V.M. (2018) Formirovanie kommunikativnoi kompetentsii studentov v processe obucheniya inostrannomu yazyku na baze LMS Moodle [Formation of communicative competence of students in the process of teaching a foreign language based on LMS Moodle]. Bulletin of Samara University. History, pedagogy, philology. V. 24. № 2. P. 63-69. URL: https://doi.org/10.18287/2542-0445-2018-24-2-63-69.

6. Sovremennyie formy udalennogo obucheniya (2020) [Modern forms of distance learning]. URL: https://edunews.ru/onlajn/info/vidy-distantsionnogo-obucheniya.html. 